\title{
UJI VALIDITAS DAN RELIABILITAS INSTRUMEN PENELITIAN KUANTITATIF
}

\author{
Febrianawati Yusup \\ Program Studi Tadris Biologi, Fakultas Tarbiyah dan Keguruan \\ Universitas Islam Negeri Antasari Banjarmasin \\ febrianawatiyusup@uin-antasari.ac.id
}

\begin{abstract}
The research instrument is a tool used to collect data or measure objects of a research variable. To obtain the correct data for the conclusion that is in accordance with the actual situation, then required a valid instrument and consistent and appropriate in providing data of research result. Instrument reliability tests to include test-retest, equivalent, and internal consistency. Internal consistency tests have several testing techniques depending on the type of instrument. Testing techniques included split half test, KR 20, KR 21, and Alfa Cronbach. The value of the validity and reliability of an instrument is influenced by the measured subject, the instrument user, and the instrument itself. Sehinggga, validity and reliability must always be tested before the instrument is used.
\end{abstract}

Key word: cotent validity; construct validity; criteria validty; test-retest; equivalent; split half; KR 20; KR 21; Alfa Cronbach

\section{ABSTRAK}

Instrumen penelitian adalah suatu alat yang digunakan untuk mengumpulkan data atau mengukur objek dari suatu variabel penelitian. Untuk mendapatkan data yang benar demi kesimpulan yang sesuai dengan keadaan sebenarnya, maka diperlukan suatu instrumen yang valid dan konsisten serta tepat dalam memberikan data hasil penelitian (reliabel). Uji reliabilitas instrumen meliputi test-retest, ekuivalen, dan internal consistency. Uji internal consistency memiliki beberapa teknik pengujian tergantung jenis instrumennya. Teknik pengujian tersebut meliputi uji split half, KR 20, KR 21, dan Alfa Cronbach. Nilai validitas dan reliabilitas suatu instrumen dipengaruhi oleh subjek yang diukur, pengguna instrumen, dan instrumen itu sendiri. Sehinggga, validitas dan reliabilitas harus selalu diuji sebelum instrumen digunakan.

Kata kunci: validitas isi; validitas konstruk; validitas kriteria; test-retest; ekuivalen; split half; KR 20; KR 21; Alfa Cronbach

\section{PENDAHULUAN}

Permasalahan menjadi sumber segala sesuatu dalam suatu penelitian. Dari permasalahan muncullah tujuan penelitian yang mengandung variabel-variabel penelitian. Untuk menjawab tujuan penelitian, diperlukan data. Data ini merupakan gambaran variabel yang diteliti. Data yang benar akan membawa pada kesimpulan yang sesuai dengan keadaan yang sebenarnya. Benar tidaknya data tergantung pada baik tidaknya instrumen pengumpul data atau pengukur objek dari suatu variabel penelitian (Arikunto, 2010).

Baik tidaknya suatu instrumen penelitian ditentukan oleh validitas dan reliabilitasnya. Validitas instrumen mempermasalahkan sejauh mana pengukuran tepat dalam mengukur apa yang hendak diukur, sedangkan reliabilitas mempermasalahkan sejauh mana suatu pengukuran dapat dipercaya karena keajegannya. Instrumen dikatakan valid saat dapat mengungkap data dari variabel secara tepat tidak menyimpang dari 
keadaan yang sebenarnya. Instrumen dikatakan reliabel saat dapat mengungkapkan data yang bisa dipercaya (Arikunto, 2010).

Validitas dan reliabilitas instrumen tidak serta-merta ditentukan oleh instrumen itu sendiri. Menurut Sugiyono (2014), faktor-faktor yang mempengaruhi validitas dan reliabilitas suatu alat ukur (instrumen) selain instrumen adalah pengguna alat ukur yang melakukan pengukuran dan subjek yang diukur. Namun, faktor-faktor tersebut dapat diatasi dengan jalan menguji instrumen dengan uji validitas dan reliabilitas yang sesuai. Pengujian dilakukan untuk menjaga validitas dan reliabilitasnya. Selain itu, untuk mengatasi pengaruh dari pengguna alat ukur, maka pengguna harus meningkatkan kemampuannya dalam menggunakan alat ukur tersebut. Satu faktor lagi yang tidak kalah penting yang mempengaruhi validitas dan reliabilitas instrumen adalah faktor subjek yang diukur. Untuk mengatasi hal tersebut, maka peneliti harus dapat mengendalikan subjek.

Meskipun suatu instrumen telah terstandard dan reliabel, tetapi hal itu tidak langsung membuat instrumen tersebut dapat digunakan dimana saja, kapan saja, kepada subjek siapa saja. Instrumen perlu diuji coba kembali setiap kali akan digunakan (Tavakol \& Dennick, 2011).

\section{PEMBAHASAN}

\section{Validitas}

Validitas instrumen dapat dibuktikan dengan beberapa bukti. Bukti-bukti tersebut antara lain secara konten, atau dikenal dengan validitas konten atau validitas isi, secara konstruk, atau dikenal dengan validitas konstruk, dan secara kriteria, atau dikenal dengan validitas kriteria.

a. Validitas Konten

Validitas konten atau validitas isi fokus memberikan bukti pada elemenelemen yang ada pada alat ukur dan diproses dengan analisis rasional. Validitas konten dinilai oleh ahli. Saat alat ukur diuraikan dengan detail maka penilaian akan semakin mudah dilakukan.

Beberapa contoh elemen yang dinilai dalam validitas konten adalah sebagai berikut.

1) Definisi operasional variabel

2) Representasi soal sesuai variabel yang akan diteliti

3) Jumlah soal

4) Format jawaban

5) Skala pada instrumen

6) Penskoran

7) Petunjuk pengisian instrumen

8) Waktu pengerjaan

9) Populasi sampel

10) Tata bahasa

11) Tata letak penulisan (format penulisan)

Setelah melakukan uji validitas konten kepada ahli, kemudian instrumen direvisi sesuai saran/masukan dari ahli. Instrumen dinyatakan valid secara konten tergantung dari ahli. Ahli bebas memberikan penilaian apakah instrumen ini valid atau tidak. Indikator bahwa suatu instrumen telah valid adalah ahli sudah menerima instrumen, baik secara isi maupun formatnya, tanpa ada perbaikan kembali. Jika setelah revisi ahli masih meminta ada perbaikan, maka revisi masih perlu dilakukan hingga ahli benar-benar menerima instrumen tanpa perbaikan lagi (Fraenkel, Wallen, \& Hyun, 2012).

\section{a. Validitas Konstruk}


Validitas konstruk fokus pada sejauh mana alat ukur menunjukkan hasil pengukuran yang sesuai dengan definisinya. Definisi variabel harus jelas agar penilaian validitas konstruk mudah. Definisi tersebut diturunkan dari teori. Jika definisi telah berlandaskan teori yang tepat, dan pertanyaan atau pernyataan item soal telah sesuai, maka instrumen dinyatakan valid secara validitas konstruk (Fraenkel, Wallen, \& Hyun, 2012).

\section{b. Validitas Kriteria}

Validitas kriteria fokus pada membandingkan instrumen yang telah dikembangkan dengan instrumen lain yang dianggap sebanding dengan apa yang akan dinilai oleh instrumen yang telah dikembangkan. Instrumen lain ini disebut sebagai kriteria. Ada dua jenis validitas kriteria: 1) Validitas Kriteria Prediktif dan 2) Validitas Kriteria Bersamaan (Concurrent) (Fraenkel, Wallen, \& Hyun, 2012).

Perbedaan kedua uji validitas kriteria tersebut terletak pada waktu pengujian instrumen dengan kriterianya. Jika pengujian instrumen dan kriterianya dilakukan pada waktu yang berbeda, maka disebut dengan validitas kriteria prediktif, sedangkan jika pengujian instrumen dengan kriterianya dilakukan pada waktu yang bersamaan maka disebut dengan validitas kriteria bersamaan (concurrent).

Hasil dari uji instrumen dan kriterianya kemudian dihubungkan dengan uji korelasi. Berikut ini disajikan rumus korelasi untuk mencari koefisien korelasi hasil uji instrumen dengan uji kriterianya.

$$
r_{x y}=\frac{n\left(\sum x_{i} y_{i}\right)-\left(\sum x_{i}\right)\left(\sum y_{i}\right)}{\sqrt{\left(n\left(\sum x_{i}^{2}\right)-\left(x_{i}\right)^{2}\right)\left(n\left(\sum y_{i}^{2}\right)-\left(y_{i}\right)^{2}\right)}}
$$

$$
\begin{aligned}
\mathrm{r}_{\mathrm{xy}}= & \text { koefisien korelasi } \\
\mathrm{n} & =\text { jumlah responden } \\
\mathrm{x}_{\mathrm{i}} & =\text { skor setiap item pada instrumen } \\
\mathrm{y}_{\mathrm{i}} \quad= & \text { skor setiap item pada kriteria } \\
& \text { Nilai koefisien ini disebut sebagai }
\end{aligned}
$$
koefisien validitas (Fraenkel, Wallen, \& Hyun, 2012). Nilai koefisien validitas berkisar antara $+1,00$ sampai $-1,00$. Nilai koefisien $+1,00$ mengindikasikan bahwa individu pada uji instrumen maupun uji kriteria, memiliki hasil yang relatif sama, sedangan jika koefisien validitas bernilai 0 mengindikasikan bahwa tidak ada hubungan antara instrumen dengan kriterianya. Semakin tinggi nilai koefisien validitas suatu instrumen, maka semakin baik instrumen tersebut.

\section{Reliabilitas}

Reliabilitas instrumen dapat diuji dengan beberapa uji reliabilitas. Beberapa uji reliabilitas suatu instrumen yang bisa digunakan antara lain test-retest, ekuivalen, dan internal consistency. Internal consistency sendiri memiliki beberapa teknik uji yang berbeda. Teknik uji relibilitas internal consistency terdiri dari uji split half, KR 20, KR 21, dan Alfa Cronbach. Namun, setiap uji memiliki kriteria instrumen seperti apa yang bisa diuji dengan teknik tersebut.

\section{a. Test-Retest}

Pengujian reliabilias dengan testretest dilakukan dengan cara mencobakan satu jenis instrumen beberapa kali pada subjek (responden) yang sama. Reliabilitas instrumen diukur dari koefisien korelasi antara percobaan pertama dengan percobaan selanjutnya. Instrumen dinyatakan reliabel jika koefisien korelasi positif dan signifikan. Korelasi antara hasil uji pertama dengan hasil uji selanjutnya diuji dengan korelasi Product Moment untuk mencari koefisien korelasinya. 
Rumus korelasi Product Moment yang digunakan seperti tersaji di bawah ini. termasuk signifikan apabila t hitung $>$ dari $\mathrm{t}$ tabel $\left(\mathrm{t}>\mathrm{t}_{\mathrm{t}}\right)$ (Sugiyono, 2014). $r_{x y}=\frac{n\left(\sum x_{i} y_{i}\right)-\left(\sum x_{i}\right)\left(\sum y_{i}\right)}{\sqrt{\left(n\left(\sum x_{i}^{2}\right)-\left(x_{i}\right)^{2}\right)\left(n\left(\sum y_{i}^{2}\right)-\left(y_{i}\right)^{2}\right)}}$

$\mathrm{r}_{\mathrm{xy}} \quad=$ koefisien korelasi Product

Moment

$\mathrm{n} \quad=$ jumlah responden

$\mathrm{x}_{\mathrm{i}} \quad=$ skor setiap item pada percobaan pertama

$$
\mathrm{y}_{\mathrm{i}}=\text { skor setiap item pada }
$$

percobaan selanjutnya

Signifikansi koefisien korelasi dapat ditentukan dengan dua cara. Cara pertama dengan membandingkan koefisien korelasi dengan tabel r Product Moment. Dikatakan signifikan jika nilai $r$ hitung lebih besar saat dibandingkan dengan $r$ tabel pada tabel $\mathrm{r}$ Product Moment $\left(\mathrm{r}_{\mathrm{i}}>\mathrm{r}_{\mathrm{t}}\right)$. Cara kedua dengan uji $\mathrm{t}$ (Sugiyono, 2014).

Berikut ini disajikan rumus uji t.

$$
\begin{aligned}
t & =\frac{r \sqrt{n-2}}{\sqrt{1-r^{2}}} \\
\mathrm{t} & =\text { nilai } \mathrm{t} \text { hitung } \\
\mathrm{r} & =\text { koefisien korelasi } \\
\mathrm{n} & =\text { jumlah responden }
\end{aligned}
$$

Setelah nilai uji t hitung diperoleh, nilai tersebut selanjutnya dibandingkan dengan harga $\mathrm{t}$ tabel. Nilai $\mathrm{t}$ tabel yang digunakan disesuaikan dengan signifikansi penelitian yang digunakan. Signifikansi yang tersedia pada t tabel antara lain 0,50 ; 0,$25 ; 0,20 ; 0,05 ; 0,02 ; 0,01$; dan 0,0005 . Namun, biasanya, dalam penelitian pendidikan, nilai signifikansi yang digunakan yaitu 0,01 atau 0,05 . Derajat kebebasan (dk) merupakan hasil jumlah responden dikurangi dua $(\mathrm{dk}=\mathrm{n}-2)$. Signifikansi korelasi antara dua instrumen

\section{Equivalent}

Pengujian reliabilias dengan uji фquivalent dilakukan dengan cara nencobakan instrumen yang berbeda tetapi ekuivalen (sebanding/sepadan). Percobaan dilakukan satu kali saja pada responden yang sama. Reliabilitas instrumen diukur dari koefisien korelasi antara percobaan instrumen satu dengan percobaan instrumen yang lainnya. Instrumen dinyatakan reliabel jika koefisien korelasi positif dan signifikan.

Pengujian koefisien korelasi dan signifikansinya dilakukan seperti pada uji test-retest menggunakan rumus korelasi Product Moment dan diuji signifikansinya menggunakan $r$ tabel atau uji t.

\section{c. Internal Consistency}

Pengujian reliabilias dengan uji internal consistency, dilakukan dengan cara mencobakan instrumen sekali saja pada subjek penelitian. Pengujian ini dapat dilakukan dengan teknik belah dua (split half) dari Spearman Brown, KR 20, KR 21, atau dengan teknik Alfa Cronbach. Hasil pengujian tersebut kemudian dianalisis dengan teknik tertentu tergantung jenis instrumennya.

\section{1) Spearman Brown (Split Half)}

Pengujian reliabilitas dengan uji internal consistency teknik split half dari Spearman-Brown dilakukan pada instrumen yang memiliki satu jawaban benar. Instrumen tersebut misalnya pilihan ganda, mencocokkan, dan yang lainnya yang hanya memiliki satu jawaban benar. Uji reliabilitas menggunakan teknik spit half dilakukan dengan cara mencobakan instrumen sekali saja pada subjek penelitian kemudian hasil uji dibagi menjadi dua. Pembagian ini biasanya didasarkan pada soal ganji-genap. Pertama, 
koefisien korelasi dari kumpulan soal ganjil dengan soal genap dihitung menggunakan rumus (2). Koefisien ini menggambarkan derajat kesamaan hasil antara kedua belahan yang menggambarkan konsistensi internal dari sebuah instrumen. Kemudian, koefisien reliabilitas dihitung menggunakan rumus yang dikenal dengan istilah SpearmanBrown.

Berikut ini disajikan rumus SpearmanBrown

$$
r_{i}=\frac{2 r_{b}}{1+r_{b}}
$$

$\mathrm{r}_{\mathrm{i}} \quad=$ reliabilitas internal seluruh instrumen

$\mathrm{r}_{\mathrm{b}} \quad=$ korelasi Product Moment antara belahan ganjil dengan belahan genap (lihat rumus (2))

Suatu instrumen dikatakan reliabel saat nilai koefisien reliabilitas Spearman-Brown lebih dari 0,70 ( $\mathrm{r}_{\mathrm{i}}>$ 0,70). Jika nilai koefisien reliabilitas Spearman-Brown kurang dari 0,70, maka jumlah soal ditambah dengan soal yang sesuai dengan aslinya (Fraenkel, Wallen, \& Hyun, 2012).

\section{2) KR 20 dan KR 21}

Teknik pengujian reliabilitas dengan uji internal consistency yang selanjutnya dibahas adalah teknik Kuder Richardson atau sering disingkat KR. Instrumen yang dapat diuji reliabilitasnya menggunakan KR adalah instrumen dengan satu jawaban benar saja. Rumus KR yang sering digunakan adalah KR 20 dan KR 21.

Kedua teknik KR tersebut memiliki kriteria instrumen khusus untuk bisa menggunakan rumusnya. Saat instrumen tidak dapat dipastikan bahwa setiap item soal memiliki tingkat kesulitan yang sama, maka instrumen tersebut dianalisis reliabilitasnya menggunakan rumus KR 20 (Fraenkel, Wallen, \& Hyun, 2012).

Berikut ini disajikan rumus KR 20 (Sugiyono, 2014).

$$
r_{i}=\frac{k}{(k-1)}\left\{\frac{s_{t}^{2}-\sum p_{i} q_{i}}{s_{t}^{2}}\right\}
$$

$$
\begin{array}{ll}
\mathrm{r}_{\mathrm{i}} & =\text { reliabilitas internal instrumen } \\
\mathrm{k} & =\text { jumlah item soal dalam } \\
& \text { instrumen } \\
& =\text { proporsi banyaknya subjek yang } \\
\mathrm{p}_{\mathrm{i}} & \text { menjawab setiap item soal } \\
& =1-\mathrm{p}_{\mathrm{i}} \\
\mathrm{q}_{\mathrm{i}} \quad \text { varians total } \\
\mathrm{s}_{\mathrm{t}}{ }^{2} \quad \begin{array}{l}
\Sigma(x-\bar{x})^{2} \\
n
\end{array} \\
\quad \text { soal dengan } \mathrm{x} \text { adalah nilai setiap } \\
\text { responden. } \mathrm{n} \text { adalah jumlah }
\end{array}
$$

Saat instrumen dapat dipastikan memiliki tingkat kesulitasn yang sama untuk setiap item soal, maka untuk menguji relibilitasnya digunakan rumus KR 21 .

Berikut disajikan rumus KR 21 (Sugiyono, 2014).

$$
r_{i}=\frac{k}{(k-1)}\left\{1-\frac{M(k-M)}{k\left(s_{t}^{2}\right)}\right\}
$$

$\mathrm{r}_{\mathrm{i}} \quad=$ reliabilitas internal instrumen

$\mathrm{k}=$ jumlah item soal dalam instrumen

$\mathrm{M} \quad$ = rata-rata skor total

$\mathrm{st}^{2} \quad=$ varians total

Menurut Fraenkel, Wallen, \& Hyun (2012) suatu instrumen dikatakan reliabel apabila nilai koefisien reliabilitas KR lebih dari $0,70\left(r_{i}>0,70\right)$.

\section{3) Alfa Cronbach}

Pengujian reliabilitas menggunakan uji Alfa Cronbach dilakukan 
untuk instrumen yang memiliki jawaban benar lebih dari 1 (Adamson \& Prion, 2013). Instrumen tersebut misalnya instrumen berbentuk esai, angket, atau kuesioner.

Rumus koefisien reliabilitas Alfa Cronbach adalah sebagai berikut.

$$
r_{i}=\frac{k}{(k-1)}\left\{1-\frac{\sum s_{i}^{2}}{s_{t}^{2}}\right\}
$$

$\mathrm{r}_{\mathrm{i}}=$ koefisien reliabilitas Alfa Cronbach

$\mathrm{k}=$ jumlah item soal

$\sum \mathrm{s}_{\mathrm{i}}{ }^{2}=$ jumlah varians skor tiap item

$\mathrm{s}_{\mathrm{t}}{ }^{2} \quad=$ varians total

Rumus varians item dan varians total,

$$
s_{i}^{2}=\frac{J K i}{n}-\frac{J K s}{n^{2}}
$$

$$
s_{t}^{2}=\frac{\sum X_{t}^{2}}{n}-\frac{\left(\sum X_{t}\right)^{2}}{n^{2}}
$$

$\mathrm{si}_{\mathrm{i}}^{2}=$ varians tiap item

$\mathrm{JKi}=$ jumlah kuadrat seluruh skor item

JKs = jumlah kuadrat subjek

$\mathrm{n} \quad=$ jumlah responden

$\mathrm{st}_{\mathrm{t}}^{2}=$ varians total

$\mathrm{X}_{\mathrm{t}} \quad=$ skor total

Jika koefisien reliabilitas Alfa

Cronbach telah dihitung $\left(\mathrm{r}_{\mathrm{i}}\right)$, nilai tersebut kemudian dibandingkan dengan kriteria koefisien reliabilitas Alfa Cronbach untuk instrumen yang reliabel. Menurut Nunnally (dalam Streiner, 2003) menyatakan bahwa instrumen dikatakan reliabel jika koefisien reliabilitas Alfa Cronbach lebih dari 0,70 $\left(r_{i}>0,70\right)$ dan Streiner sendiri (2003) menyatakan bahwa koefisien reliabilitas Alfa Cronbach, tidak boleh lebih dari $0,90\left(r_{i}<0,9\right)$.
Jika koefisien reliabilitas Alfa Cronbach kurang dari $0,70\left(\mathrm{r}_{\mathrm{i}}<0,70\right)$, Tavakol \& Dennick (2011) menyarankan untuk merevisi atau menghilangkan item soal yang memiliki korelasi yang rendah. Cara mudah menentukan item soal tersebut adalah dengan bantuan program di komputer. Jika koefisien reliabilitas Alfa Cronbach lebih dari 0,90 ( $\left.r_{i}>0,90\right)$, mereka pun memiliki saran. Mereka menyarankan untuk mengurangi jumlah soal dengan kriteria soal yang sama meskipun dalam bentuk kalimat yang berbeda.

\section{Kesimpulan}

Instrumen memiliki kedudukan yang penting dalam penelitian karena instrumen berperan dalam proses pengambilan data. Instrumen yang valid dan reliabel dapat menghasilkan data yang valid dan reliabel pula sehingga membawa pada kesimpulan yang sesuai dengan keadaan sebenarnya.

Validitas mempermasalahkan sejauh mana pengukuran tepat dalam mengukur apa yang hendak diukur. Ketepatan dinilai dengan validitas konten, validitas konstruk, dan validitas kriteria. Ketepatan konten dan konstruk dinilai oleh ahli pada bidangnya. Instrumen dinyatakan valid secara konten dan konstruk apabila ahli sudah tidak memberikan saran/masukan dan menerima isi, format, serta konstruk dari instrumen tersebut. Ketepatan kriteria dinilai dengan membandingkan instrumen dengan kriterianya. Perbandingan diuji dengan uji korelasi. Semakin nilai koefisien validitas mendekati $+1,00$ maka instrumen diindikasi semakin valid.

Reliabilitas mempermasalahkan sejauh mana suatu pengukuran dapat dipercaya karena keajegannya. Suatu instrumen dengan pilihan jawaban 2 atau 
lebih, dikatakan reliabel apabila dalam beberapa kali pelaksanaan pengukuran terhadap subjek yang sama (test-retest) diperoleh hasil yang relatif sama atau dalam satu kali pengukuran dengan instrumen yang berbeda (equivalent) diperoleh hasil yang relatif sama. Suatu instrumen dengan pilihan jawaban yang hanya dua saja, dikatakan reliabel apabila nilai $r_{i}>r_{t}$, sedangkan untuk instrumen dengan pilihan jawaban lebih dari dua, dikatakan reliabel apabila koefisien reliabilitas Alfa Cronbach di antara 0,700,90 .

\section{DAFTAR PUSTAKA}

Adamson, K. A. \& Prion, S.. (2013). Reliability : measuring internal consistency using cronbach's $\alpha$, Clinical Simulation in Nursing, 9, hlm. 179-180.

Arikunto, Suharsimi. (2010). Prosedur penelitian : suatu pendekatan praktik. Jakarta : Rineka Cipta.

Fraenkel, J. L., Wallen, N. E., \& Hyun, H. H.. (2012). How to design and evaluate research in education eighth edition. New York : Mc Graw Hill.

Streiner, D. L.. (2003). Starting at the beginning : an introduction to coefficient alpha and internal consistency, Journal of Personality Assessment, 80 (1), hlm. 99-103.

Sugiyono. (2014). Statistika untuk penelitian. Bandung : Alfabeta.

Tavakol, M. \& Dennick, R.. (2011). Making sense of cronbach's alpha, International Journal of Medical Education, 2, hlm. 53-55. 